\title{
Cytological changes connected with the process of adaptation to ow temperatures in the coleoptile epidermis of Agropyron glaucum
}

\author{
M. KWIATKOWSKA
}

The seasonal increase in resistance of plants to low temperatures appearing in the autumn-winter period, and disappearing in spring and summer is the object of interest of investigators in many biological branches. The explanation of this phenomenon is sought for in studies on the specific biochemical, physiological and cytological changes associated with the increase in hardiness as well as in investigations on the causes of death brought on by heavy frost. In spite of the extensive literature devoted to this problem, a number of questions remain unsolved, and the results of observation reported by various authors, and their views on the subject are often controversial. One of the causes of this seems to be the insufficient number of complex cytological-physiological-biochemical investigations performed on comparable objects subjected to identical experimental conditions, since even slight methodical differences may yield completely inconsistent results (Aleksandrov 1964; Moroz 1966; Rotténburg 1968).

In investigations on the influence of lowered temperatures on the morphology of mitochondria (Kwiatkowska 1970) the author also performed, among other studies, observations on plants subjected to two-step adaptation according to the method used in physiological and biochemical tests on the hardiness of cereals. This method is based on Tumanov's theory claiming that plants with a genetic ability of adaptation to low temperature become hardened in two phases (Tumanov 1951, 1960). The first occurs in the period of autumn cool weather at temperatures around $5^{\circ}$ to $0^{\circ} \mathrm{C}$, and begins by a strong inhibition of growth. In this phase accumulation of protective substances occurs. These substances are mainly sugars derived from photosynthesis in the cereal leaves (Andersson 1944) or from transformation of starch to simple sugars when cereal seedlings are injured by cold (Tumanov 1951). The second phase of adaptation takes place at negative temperatures (below $-3^{\circ}$ ). In this period the permeability of the protoplast to water increases and so does the ability of the plant to produce extracellular ice in the course of freezing of the tissues. Owing to this, the cell structure remains intact. In both phases, as surmised by Tumanov (1960), there presumably occur changes in the cell ultrastructure, increasing the thermal resistance of the plant. So far morphological data are not available concerning these transformations of the protoplast. This prompted the author to confront other cytological changes (observed together with the changes in the mitochondria) associated with the process of adaptation of Agropyron seedlings, 


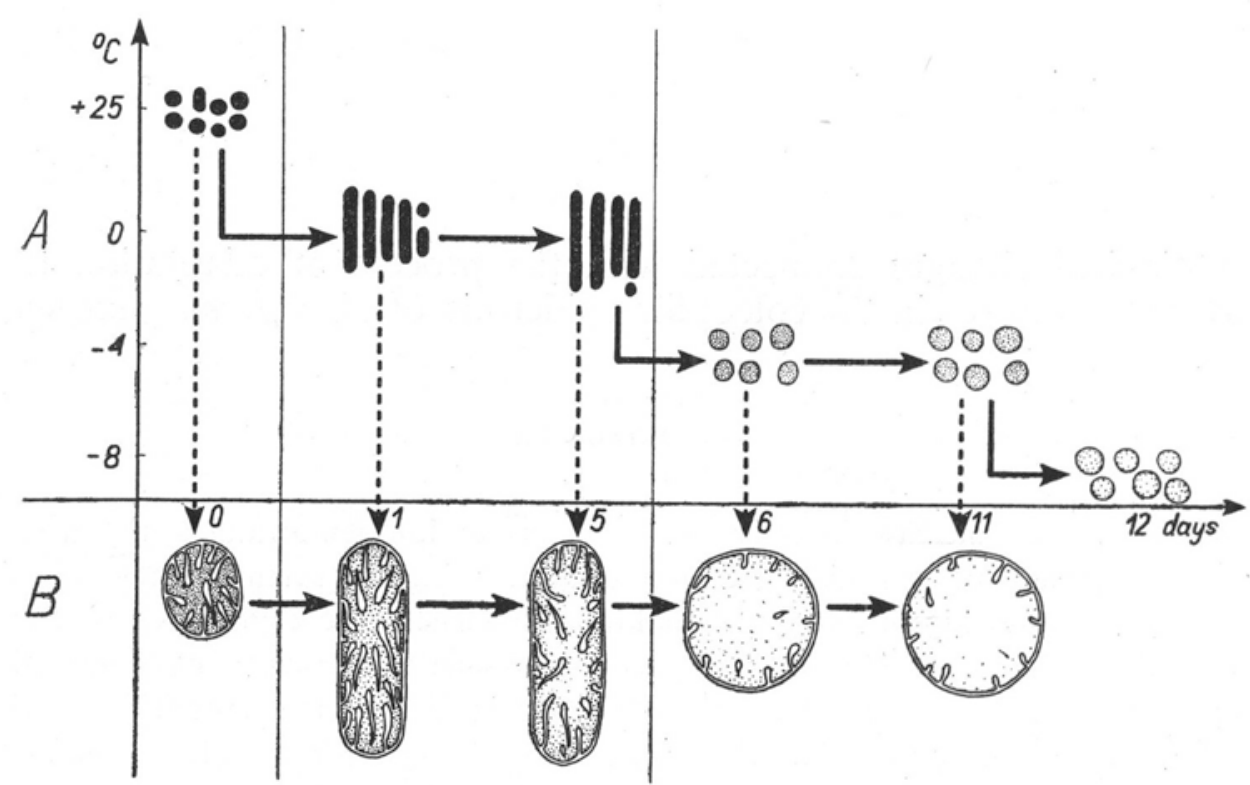

Fig. 1. Morphological changes in mitochondria occurring during two-phase adaptation of Agropyron glaucum seedlings

The observations concern epiderm is of $25-\mathrm{mm}$ coleoptiles at a distance of ca. $2 \mathrm{~mm}$ from apex $A-$ In vivo observations (shape and size of mitochondria); $B$ - Changes in ultrastructure of mitochondria

and which she did not take into account in the above quoted publication Kwiatkowska 1970.

The observations were made in vivo on epidermal cells of the apical part of the Agropyron coleoptile. The preparations were made from 25 -mm coleoptiles cultivated in the dark at $25^{\circ} \mathrm{C}$ in Petri dishes lined with filter paper moistened with tap water. They were then exposed in a refrigerator to $0^{\circ} \mathrm{C}$ for $5-7$ days (I phase) and the to $-4^{\circ} \mathrm{C}$ also for $5-7$ days (phase II). The in vivo observations were performed at about $20-25^{\circ} \mathrm{C}$ in the controls or in a cold room ca. $0^{\circ} \mathrm{C}$ during and after phase I, and at $-4^{\circ} \mathrm{C}$ in phase II of adaptation. The epidermis sections of coleoptile fragments from chilled plants were placed in silicon oil (Crossman 1967). The same coleoptile sections were fixed in glutaric aldehyde at $1^{\circ} \mathrm{C}$ with postfixation in osmium tefroxide without defreezing. Ultrathin sections for observation in the electron microscope were stained in lead acetate.

\section{CHANGES ASSOCIATED WITH PHASE I OF ADAPTATION}

Mitochondria. From the results already described, it is seen in fig. 1 that for phase I of adaptation, from the first to the last day of its duration, the occurrence of mitochondria predominantly in the form of long rods is characteristic, in contrast with the plants growing at $25^{\circ} \mathrm{C}$ which mostly exhibited spherical mitochondria. The 


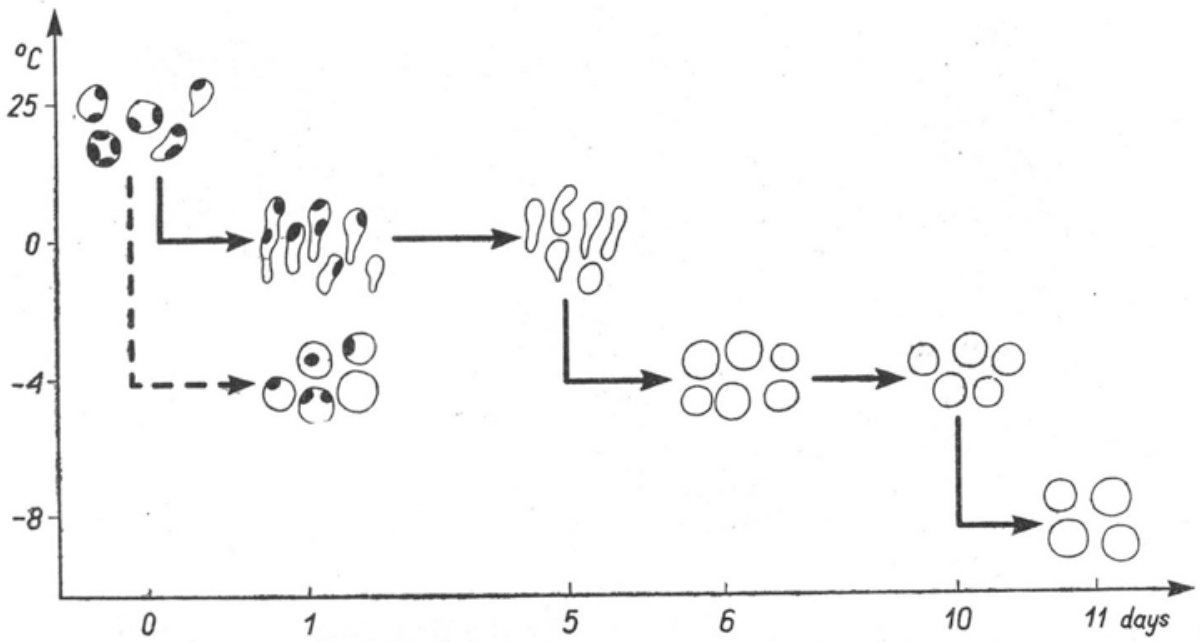

Fig. 2. Shape and size of plastids observed in living coleoptile cells of A. glaucum in control conditions $\left(+25^{\circ} \mathrm{C}\right)$ and in plants subjected to chilling:

a) $\rightarrow$ during two-phase adaptation; b ) $\rightarrow$ in seedlings transferred directly from $+25^{\circ} \mathrm{C}$ to $-4^{\circ} \mathrm{C}$

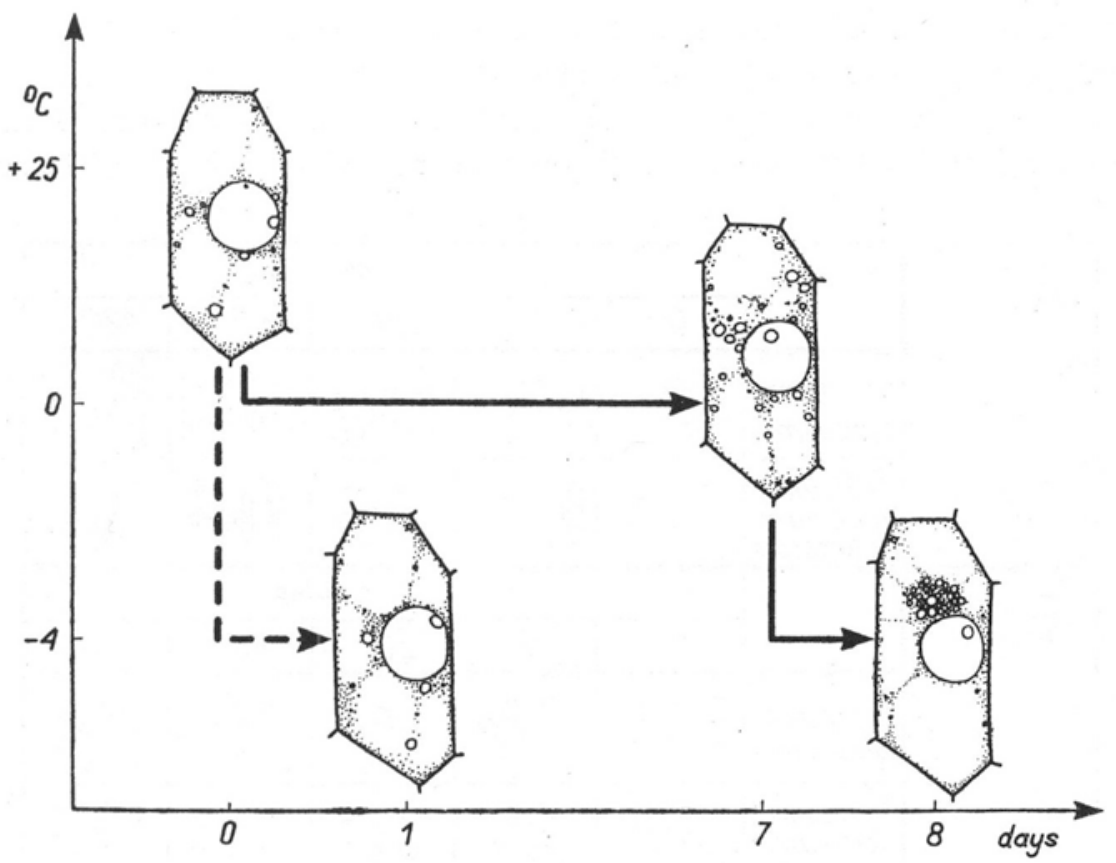

Fig. 3. Lipids and spherosomes in apical cells of coleoptile of A: glaucum in control conditions and during chilling:

a) $\rightarrow$ submitted to two-phase adaptation, $b) \rightarrow$ cels from seedlings transferred directly from $+25^{\circ} \mathrm{C}$ to $-4^{\circ} \mathrm{C}$ 

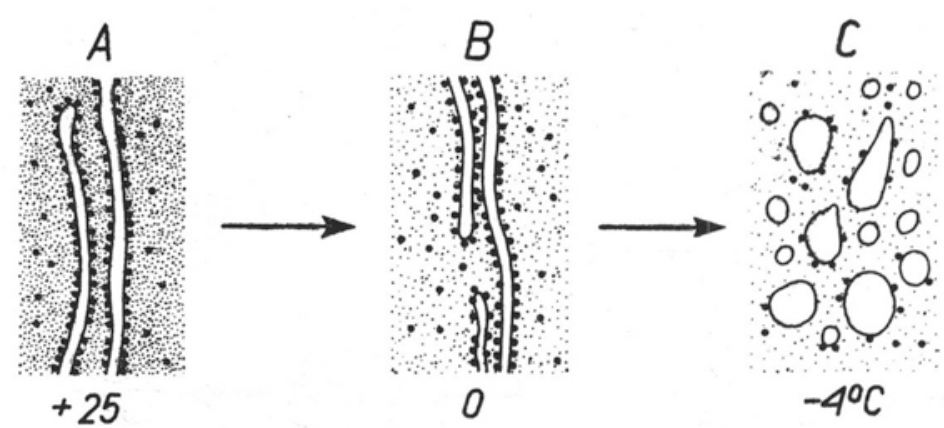

Fig. 4. Changes in ultrastructure of cytoplasm in coleoptile epidermis cells of A. glaucum during adaptation of seedlings:

$A$ - cytoplasm in control conditions, $B$ - after phase I of adaptation, $C$ - after phase II of adaptation

ultrastructure of the mitochondria at first (for the first $24 \mathrm{hrs}$.) does not undergo changes. Only after several days, i.e. towards the end of phase I can a clarification of the mitochondrial matrix be noticed.

Plastids. In the control plants (kept at $25^{\circ} \mathrm{C}$ ) plastids show in the course of translocation in the cytoplasm a considerable plasticity, assuming various forms, spherical, slightly elongated or sometimes club-like. Each of them contains starch grains on its periphery (fig. 2). About four hours after transferring the seedlings to $0^{\circ} \mathrm{C}$, the plastids stretch, elongate and become narrower assuming various forms and as in control conditions, incessantly change their shape. Starch is at first still present, however, towards the end of phase I it disappears completely.

Lipid droplets and spherosomes. In the lower and middle part of the coleoptile there are but few spherosomes in the epidermis (Plate I, photo 2). The nearer

\begin{tabular}{|c|c|c|c|c|c|c|}
\hline \multirow{4}{*}{$A$} & & \multicolumn{5}{|c|}{ minutes } \\
\hline & & 0 & 5 & 20 & 45 & 120 \\
\hline & $\begin{array}{l}\text { Agropyron } \\
\text { glaucum }\end{array}$ & $\begin{array}{l}00 \\
000 \\
00\end{array}$ & 10 & & 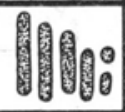 & \\
\hline & $\begin{array}{l}\text { Triticum } \\
\text { aestivum } \\
\text { v. lutescens }\end{array}$ & ${ }_{0}^{0} 0^{\circ}$ & $19 \operatorname{ll}_{0}$ & 190 & $\mathrm{C}^{1} 0^{\circ}$ & \\
\hline \multirow{4}{*}{ B } & & \multicolumn{5}{|c|}{ minutes } \\
\hline & & 0 & 5 & 20 & 45 & 120 \\
\hline & $\begin{array}{l}\text { Agropyron } \\
\text { glaucum }\end{array}$ & $\begin{array}{l}000 \\
000\end{array}$ & $\begin{array}{l}0.0 \\
00\end{array}$ & $\begin{array}{l}\theta_{0}^{\circ} \\
0\end{array}$ & $\because 000$ & $\because 0_{0}^{0}$ \\
\hline & $\begin{array}{l}\text { Triticum } \\
\text { aestivum } \\
\text { v.lutescens }\end{array}$ & ${ }_{0}^{0} 0_{0}^{\circ}$ & $\begin{array}{l}0 \\
0 \\
0 \\
0\end{array}$ & $\begin{array}{l}00 \\
00 \\
0\end{array}$ & $\because 0$ & $\because \because \theta$ \\
\hline
\end{tabular}

Fig. 5. Changes in shape of mitochondria in seedlings defrosted from $-4^{\circ} \mathrm{C}$ to room temperature: $A$ - plants adapted for 5 days at $0^{\circ} \mathrm{C}$ and $24 \mathrm{hrs}$. at $-4^{\circ} \mathrm{C} ; B$ - plants adapted for 5 days at $0^{\circ} \mathrm{C}$ and 7 days at $-4^{\circ} \mathrm{C}$ 


\section{Plate I}
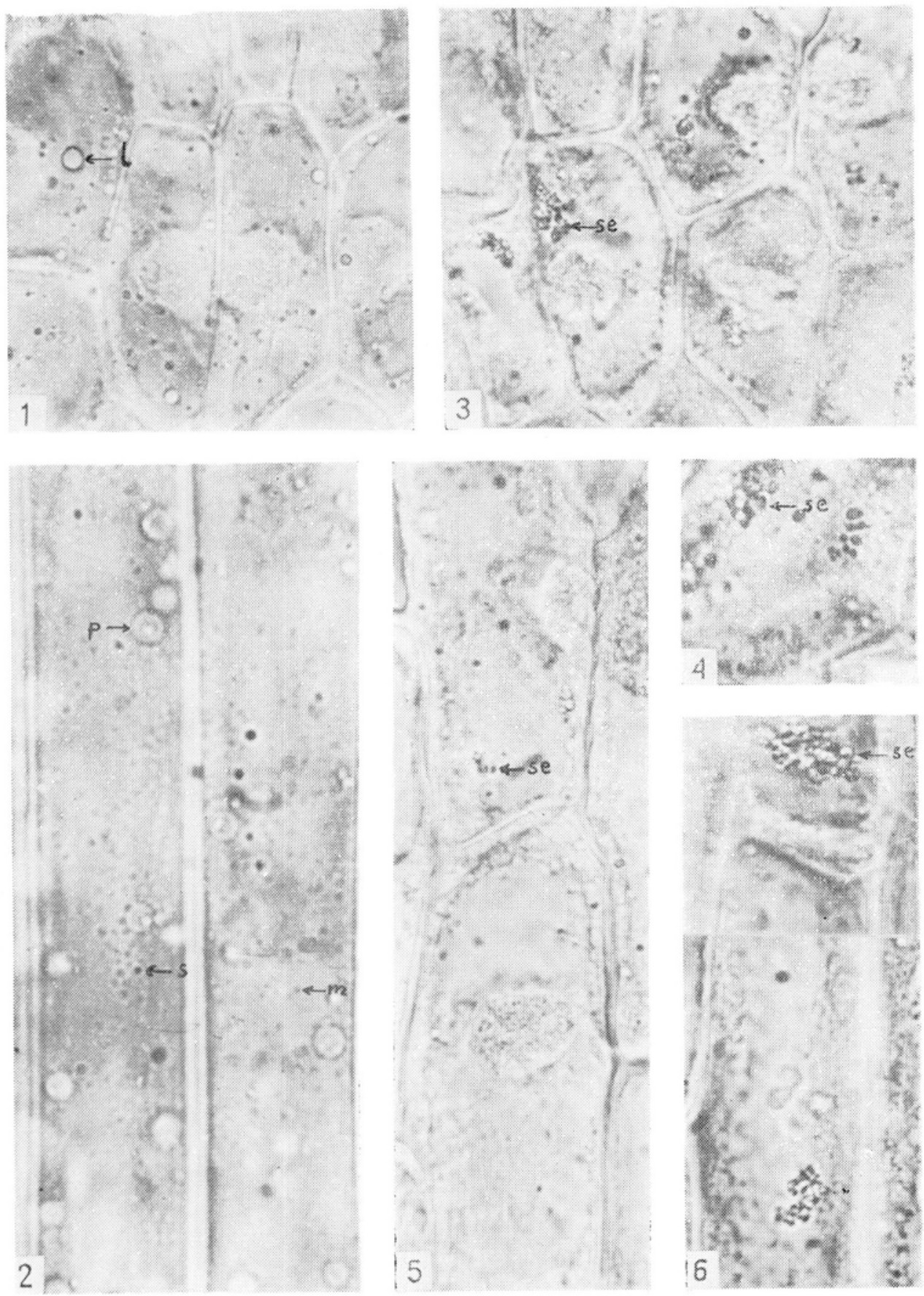

Lipid aggregations resembing elaioplasts in coleoptile epidermis of Agropyron glaucum adapted to cold at $0^{\circ} \mathrm{C}$ and $-4^{\circ} \mathrm{C}$. Living cells.

Photos 1 and 2 - cells of control seedlings $\left(\right.$ at $\left.+25^{\circ} \mathrm{C}\right): 1-$ cells from coleptile apex, 2 - cells from about $2 \mathrm{~mm}$ from apex.

Photos $3,4,5,6$ - cells of plants chilled 7 days at $0^{\circ} \mathrm{C}$ and $24 \mathrm{hrs}$. at $-4{ }^{\circ} \mathrm{C}: 3$ and $4-$ epidermis cells from coleoptile apex, 5 and $6-$ cells 1 and $2 \mathrm{~mm}$ distant from apex.

Notations: $s$-spherosomes, $l$ - lipid droplets, $s e-$ aggregations resembling elaioplasts, $m-$ mitochondria, $p-$ plasids. $\times 1200$. 

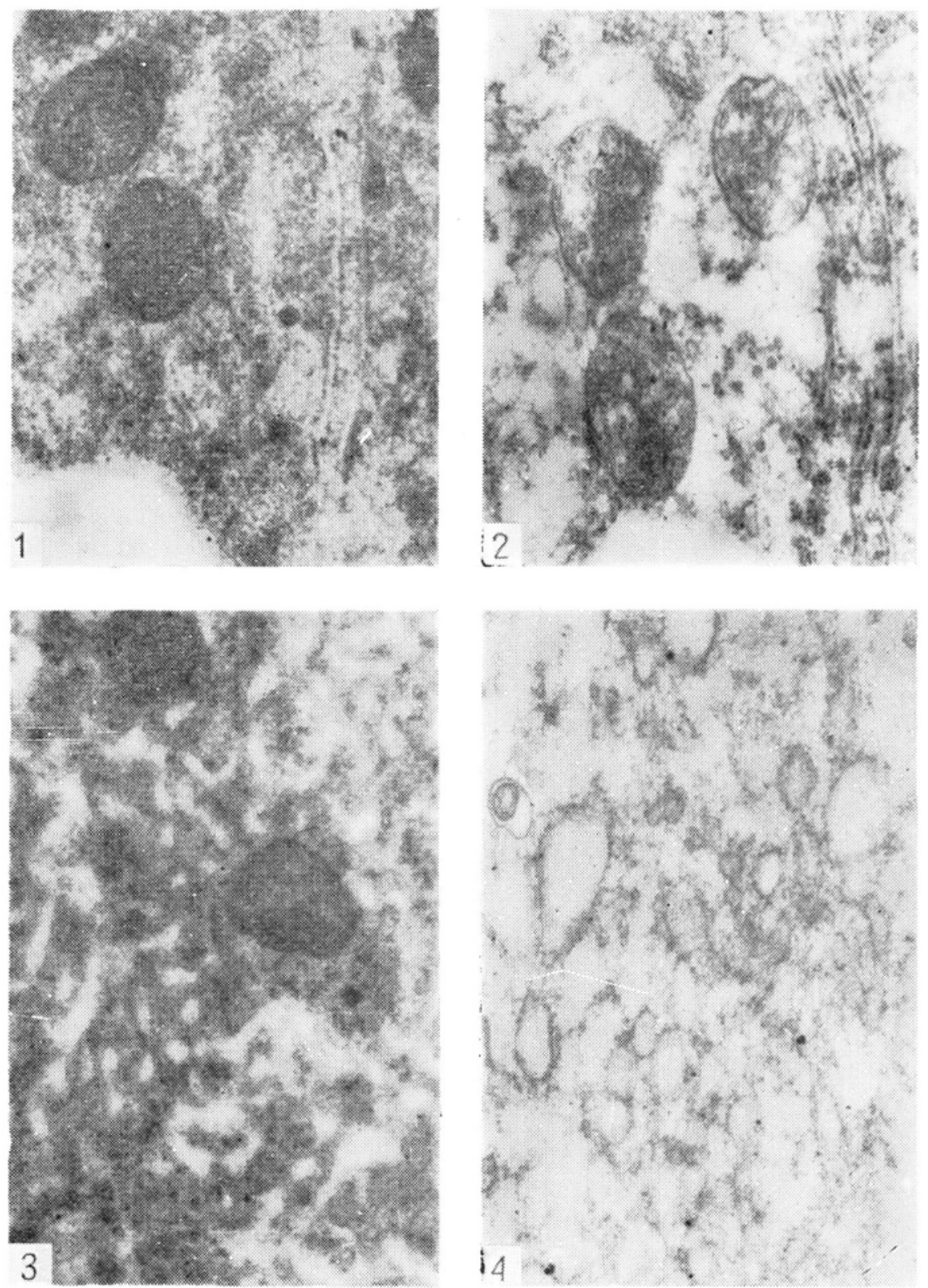

Changes in ultrastructure of epidermis cell cytoplasm in coleoptiles of Agropyron glaucum under the influences of low temperatures. Material fixed in glutaric aldehyde and postfixed in osmium tetroxide without previous defrosting.

Photo 1. cytoplasm of control coleoptiles $\left(25^{\circ} \mathrm{C}\right)$

Photo 2. coleoptiles subjected to phase I of adaptation $\left(0^{\circ} \mathrm{C}\right.$ for 7 days)

Photo 3. coleoptiles after one day of phase II adaptation $\left(-4^{\circ} \mathrm{C}\right)$

Photo 4. cytoplasm of epidermis of seedlings transferred directly from $+25^{\circ} \mathrm{C}$ to $-4^{\circ} \mathrm{C}$ for $24 \mathrm{hrs}$. 
the coleoptile apex the greater the number of grains corresponding to spherosomes. Apart from the latter lipid droplets of various sizes occur on staining with Sudan III and IV (Plate I, photo 1). The number of these droplets varies from one individual to another, both in control conditions and in the chilled plants. Nevertheless, it is clearly seen that the plants which have passed through phase I of hardening contain more lipid droplets than the controls (Fig. 3).

Cytoplasm. In the preparations of plants injured at $0^{\circ} \mathrm{C}$ and inspected in silicon oil, a lively moveinent of the cytoplasm could be seen. In the election microphotographs the lattei has a structure resembling that of the cytoplasm of the control plants: in it parallelly arranged to the long axis of the cell there occur cisterns of the endoplasmic reticulum with ribosomes on their surface, which are even more contrasting than in the control cells (Plate II, photos 1 and 2 and Fig. 4), particularly towards the end of phase I. The most significant difference as compared to the controls is the distinct clarification of the basic cytoplasm. This clarification occurs gradually reaching its maximum towards the end of phase I.

\section{CHANGES CONNECTED WITH PHASE II OF ADAPTATION (AT $-4^{\circ} \mathrm{C}$ FOR 7 DAYS)}

The lower thermal limit for phase I of cereal hardening experimentally determined by Tumanova and Trunova (1963) is a temperature of $-3^{\circ} \mathrm{C}$. It is striking that this is at the same time the lowest temperature at which part of the mitochondria still has the shape of long rods (Kwiatkowska 1970). The passage to the second phase of adaptation (below $-3^{\circ} \mathrm{C}$ ) is associated with marked transformations both of mitochondria and other cellular structures.

Mitochondria undergo swelling in the conditions of phase II, assuming a spherical shape. Frequently, aggregations of mitochondria may be observed moving in the cytoplasm in large groups. In electron microscope photographs a distinct change in their ultrastructure is visible. Their cristae are more or less reduced, and they are almost deprived of the electron-dense matrix so characteristic for the mitochondria of unchilled plants. In the ultrastructure of mitochondria at the beginning of phase II and after its end, no differences were seen. On the other hand, in living cells, after defrosting of the seedlings, the seemingly similar mitochondria behave differently. In the plants kept for only one day in phase II conditions, the rapid transformation of the mitochondria into the elongated form, characteristic of phase I (Fig. 5A) was observed. A similar process was to be followed in the leaves of plants hardened in field conditions, transferred in winter to room temperature and defrosted in melting snow. In the epidermis cells at first spherical mitochondria could be seen which after about 2 hrs. assumed the shape of very long filaments (up to $7 \mu$ ). Contrary to expectation, in seedlings subjected to the full process of adaptation in phase I and II, no such elongation was noted after their defrosting. Only their diameter diminished to the dimension characteristic of the control plants (Fig. 5 B). The swollen mitochondria of nonhardened plants subjected immediately to $-4^{\circ} \mathrm{C}$ for 24 hrs. transformed in an identical way. The difference in the behaviour of mito- 
chondria of adapted coleoptiles and of leaves of the hibernating tillering nodes could be associated with the specific properties of the coleoptile which has a short life span, rapidly ages and dies. In view of this specific feature of the material some caution is necessary in the generalization of the observations presented here to cells of other organs.

Plastids. In phase II of adaptation they exhibit, like mitochondria, a spherical shape and are swollen. At the same time they become less plastic - while shifting in the cells they do not change their shape so often. Swelling of plastids at $-4^{\circ} \mathrm{C}$ occurs both in plants inured previously at $0^{\circ} \mathrm{C}$ and those transferred directly from room temperature (Fig. 2).

Lipid droplets and spherosomes. In the plants subjected to phase II treatment, already in the first day of exposure to $-4^{\circ} \mathrm{C}$ a characteristic phenomenon is observed. The lipid droplets uniformly dispersed in the previous phase and spherosomes form here clusters of various shapes and sizes (Plate I, photos 3-6). These aggregations appeared in some of the plants only in the short apical cells of the coleoptile (Plate I, photos 3 and 4), whereas in other cells they were also present in the more elongated cells af a $1-2 \mathrm{~mm}$ distance from the apex (photo 6). The appearance of the aggregations 1esembles elaioplasts of nonplastid origin occurring periodically in the development cycle of some plants (Wałek-Czernecka, Kwiatkowska 1961; Kwiatkowska 1961, 1966). These aggregations stain like elaioplasts with Sudan III and IV. Their durability is, however, limited and associated with the temperature. After transferring the plants to room temperature, these aggregations disperse again into single droplets after a lapse of a dozen or so hours. In plants transferred from $25^{\circ} \mathrm{C}$ directly to $-4^{\circ} \mathrm{C}$ no clusters resembling elaioplasts formed after $24 \mathrm{hrs}$. (Fig. 3).

Cytoplasm. At $-4^{\circ} \mathrm{C}$ the cell cytoplasm, inspected in silicon oil, shows further flow, both in plants kept at this temperature for only $24 \mathrm{hrs}$. and in those hardened for 7-14 days. In the cytoplasm ultrastructure significant changes occur. The endoplasmic reticulum membranes, which both in the control seedlings and in those subjected to phase I of adaptation, formed long parallel cisterns, undergo fragmentation and transform into numerous vacuoles and vesicles of various sizes (Plate II photo 1 and Fig. 4).

\section{DISCUSSION}

The cytological changes associated with phase I of adaptation to cold of Agropyron seedlings are diametrally different from those occurring in phase II in all the cell structures. Phase I is characterized by a strong tendency to elongation of the cell organelles. The transition to phase II causes the mitochondria plastids and the endoplasmic reticulum to assume a spherical form. This change of shape is accompanied by a swelling of all these structures, perhaps owing to the increased ability of binding water by the protoplast colloids, observed by various authors. (Bieb1 1962). 
The appearance of the cytoplasm and mitochondria in phase I seems to confirm the results of investigations which demonstrated that a temperature close to $0^{\circ} \mathrm{C}$ does not completely inhibit the processes of synthesis (i.a. Olszewska and Rodkiewicz 1963; Grif 1966; Siminovitch et al. 1967). According to the latter authors, the continuation in the periods of autumn cold weather of RNA, DNA and protein synthesis with simultaneous, almost complete, inhibition of mitosis and elongation growth of cells leads to an increase in the weight of the nucleus and of the whole protoplast. These authors attribute a particularly important role to RNA, the high accumulation of which in the cells of tree bark precedes and catalyses all other changes connected with an increase in hardiness of plants having a genetic ability of adaptation to low temperatures. In the first place, these changes involve the high molecular weight proteins which easily undergo denaturation, and which are replaced by molecules of soluble proteins which are not precipitated by cold. The increased content of soluble proteins in plants in the period of increased resistance to cold is also reported by Yoschida and Sakai (1967) and Morton (1969). There is reason to believe that the clarification of the basic cytoplasm and mitochondrial matrix so characteristic for phase I of Agropyron adaptation may also be the effect of the exchange of the high molecular weight proteins which in the control plants give, after fixation sediments, visible in the electron microscope, for soluble proteins which can be washed out in the fixation process.

Characteristic for phase $\mathrm{I}$ is also the disappearance of starch grains in the plastids. It is probable, according to the opinion of Tumanov (1960), that they undergo hydrolysis to simple sugars with antidenaturation properties (U11rich and Heber 1957, 1958; Heber 1964 et al.).

The increase in the amount of lipids is a typical finding described for a long time in literature in various organisms and tissues exposed to cold (Barskaya 1967, and others). In the case of coleoptile epidermis, however, the lipids appear only in the cells nearest the apex. This fact indicates that the specifity of the adaptation reaction not only concerns various organisms, but also the same tissue and organ depending on the situation of the investigated cells in it, and on their physiological function.

In phase II of adaptation the author observed the appearance of lipid accumulations ressembling elaioplasts. The aggregation of various structures at temperatures below $0^{\circ} \mathrm{C}$ is rather common. As already mentioned, in the coleoptiles at this temperature the mitochondria also aggregate. Tkaczuk (1966) also observed agglomerations of mitochondria in hibernating pea leaves. Still more frequent reports concern the clustering of chloroplasts in evergreen plants in the winter months (i.a. Mikulska 1957; Barskaya 1967). This phenomenon might be referred to the changes in the physical properties of the cytoplasm, and particularly its viscosity. In the pertinent literature, however, there is no univocal opinion as to whether the increased resistance to frost due to adaptation is associated with an increase (Levit 1956; Jeremias 1956; Krisai-Knyrim Dietlinde 1960), or, on the contrary, 
with a decrease of viscosity of the cytoplasm (Höfler 1958; Thimann and Kaufmann 1958).

The general picture of the cells, both at the beginning and at the end of phase II, indicates a transition of all the structures to a state of inactivity. This concerns, in the first place, mitochondria which exhibit an ultrastructure characteristic for mitochondria incapable of phosphorylation: they are poor in matrix, have reduced cristae and are swollen (Lehninger 1964; Maszanckij et al., 1965; Ivanova and Semikhatova 1966 and others). The endoplasmic reticulum has also an appearance typical for aging or inactive tissue - it is vesicular and almost deprived of ribosomes. Similar changes in the reticulum have been observed, for instance, in the process of fruit ripening, dying cotyledons of Pisum sativum (Baine and Mercer 1964, 1966), in the differentiation of the metaxylem vessels (Buvat 1964; Cronshaw, Wardrop 1964 and others) and in older tapetum cells of Larix decidua (Mikulska et al. 1969). This specific appearance of the reticulum and mitochondria in phase II of adaptation should be connected with the hardening process, and not the influence of lower temperatures, since mitochondria of plants transferred for $24 \mathrm{hrs}$. to $-4{ }^{\circ} \mathrm{C}$ without previous adaptation at $0^{\circ} \mathrm{C}$ do not differ in their ultrastructure from those of control plants (Plate II, photos 1 and 3), whereas plants adapted in phase $\mathrm{I}$, and exposed to $-4^{\circ} \mathrm{C}$ for the same length of time have mitochondria with a greatly changed ultrastructure (Fig. 1).

The observations regarding the endoplasmic reticulum are similar. Plants suddenly chilled from $25^{\circ} \mathrm{C}$ to $-4^{\circ} \mathrm{C}$ do not exhibit the vesicular reticulum characteristic of phase II, neither is their basic cytoplasm permeable (Plate II, photo 3). On the other hand, there occur in the latter, light streaks alternating with very dense basic cytoplasm, which may be traces left by minute ice crystals. Similar pictures are described by Pease (1967) in the case of sudden exposure of cells to rapid freezing.

The results of physiological investigations on the properties of cytoplasm prove that in cells adapted to cold, the permeability of the cytoplasm to water and dielectrolytes increase proportionally to the increase in hardiness (Höfler 1949, 1958; Sakai 1955; Biebl 1962). This phenomenon is considered of great importance since, owing to it, the water contained in the protoplasm can pass quickly to the intercellular spaces, and ice crystals which could injure the cell structure do not form within it. On the other hand, Jackman and Steveninck (1967) demonstrated that the shape of the reticulum and the velocity of ion migration from cells washed with distilled water are closely related. The washing out of $\mathrm{K}$ and $\mathrm{Na}$ ions is most intensive in the first period when in the cytoplasm the tubular reticulum is disintegrating to a vesicular form. As the elongated cisterns of the reticulum are reconstructed, the intensity of ion migration decreases. The phenomena described lead to the conclusion that the change in the configuration of the endoplasmic reticulum membranes occurring in Agropyron in phase II of adaptation, i.e. the vesicularization, may be connected with the increase in the permeability of the cytoplasm to water, and thus, with the increased resistance of the cells to frost.

The typical property of all cell structures of plants adapted to cold of assuming a spherical form suggests that it is this shape that protects them from the noxious 
effects of further falls in temperature. The mitochondria and plastids swell and become rounded at temperatures below $-3^{\circ} \mathrm{C}$, both in plants adapted and not adapted to cold, whereas the cytoplasm acquires the ability of vesicularization only if the plant is submitted to an adaptation process.

\section{SUMMARY}

The epidermis of Agropyron glaucum L. seedling coleoptiles cultivated in darkness at $+25^{\circ} \mathrm{C}$ and subjected to two-step adaptation to cold was investigated. In vivo observations were performed in a light microscope, and the material fixed in glutaric aldehyde and postfixed in osmium tetroxide was studied in the electron microscope.

For phase $\mathrm{I}$ of adaptation of seedlings $\left(0^{\circ} \mathrm{C}\right.$ for about 7 days $)$ the following is characteristic a) the appearance of mitochondria in the shape of long rods, and a gradual clarification of their matrix; b) elongation of plastids and disappearance of starch in them; c) clarification of basic cytoplasm without any change in the endoplasmic reticulum configuration; d) an increase in the number of lipid droplets in the most apically situated cells of the epidermis.

Phase II ( $-4^{\circ} \mathrm{C}$ for about 7 days) is characterized by: a) swelling of the mitochondria and further clarification of their matrix and reduction of cristae; b) swelling of plastids; c) disintegration of reticulum cisterns to vaculoes and vesicles with a reduction in the number of the adjacent ribosomes; d) aggregation of lipid dioplets into structures resembling elaioplasts.

The appearance of phase I cells seems to indicate that processes of synthesis occur in them. The cytoplasm and mitochondria in phase II exhibit characteristics of inactive or degenerating tissues.

The author wishes to express her thanks to the Management of the Institute of Cytology and Genetics, Siberian Division, Academy of Sciences of USRR in Novosybirsk for enabling her to perform the experiments and take photographs in the electron microscope.

Department of Plant Anatomy and Cytology

The University of Lódź

Łódź, ul. Nowopoludniowa 12

(Entered: December 23, 1969)

\section{REFERENCES}

Aleksandrov V. Ja., 1964, Problema avtorjegulacii v citołogii. II. Reparatornaja sposobnost' kletok, Citołogija 4 (2): 133-151.

Andersson G., 1944, Gas change and frost hardening studies in winter cereals, Lund, Häken Ohlssons Boktyckeri.

Bain J. M., Mercer F. V., 1964, Organization resistance and the respiration climateric, Austral. J. Biol. Sci. 17: 78-85.

Bain J. M., Mercer F. V., 1966, Subcellular organization of the cotyledons in germinating seeds and seedlings Pisum sativum L., Austral. J. Biol. Sci. 19 (1): 69-84.

Barskaja Je. I., 1967, Izmjenjenije chłoropłastov i vyzrjevanije pobjegov v svjazi s morozoustojczivostju drjevjesnych rastjenij. Moskva, izd. Nauka.

Biebl R., 1962, Protoplasmatishe Ökologie der Pflanzen Wasser und Temperatur, Protoplasmatologia, Bd. XII, Wien, Springer Verlag.

Buvat R., 1964, Infrastructures protoplasmiques des vaisseaux du métaxylème de Cucurbita pepo au cours de leur différenciation, C. r. Acad. sci. 258: 5243-5246.

Cronshaw J., Wardrop A. B., 1964, The organization of cytoplasm in differentiating xylem, Austral. J. Bot. 12: 15-23. 
Crossmon G. G., 1967, The use of silicones as sealants for living cell preparations, Microscope 15 (9): $346-350$.

Grif W. T., 1966, O vozmożnosti sintjeza nukleinovych kisłot i bjełka pri nizkich tjempjeraturach, Citołogija 8 (5): 659-662.

Höfler K., 1949, Über Wasser- und Harnstoffpermeablität des Protoplasmas, Phyton 1: 105-121. Höfler K., 1958, Permeabilitätsstudien an Parenchymzellen der Blattrippe von Blechnum spicant. S. B. Wien Akad. Wiss., Math.-nat. Kl., Abt. 1, 167: 237-295.

Heber I., 1964, Biochimiczjeskije i fiziołogiczjeskije aspjekty morozoustojczivosti rastjenij [v sb.:] Kletka i tjempjeratura srjedy, Moskva-Leningrad, Nauka.

Ivanova T.I. i Semikhatova O. A., 1966, Diejstvije zamorożivanija na okislitjelnoje fosforilirovanije mitochondrij prorostkov gorocha, Bot. żurn. 51 (9): 1266-1275.

Jackman M.E., Van Steveninck R. F. M., 1967, Changes in the endoplasmic reticulum of beetroot slices during aging, Austral. J. Biol. Sci. 20: 1063-1068.

Jeremias K., 1956, Zur Physiologie des Frosthärtung, Planta 47: 81-104.

Krisai-Knyrim, Dietlinde, 1960, Über das osmotische Verhalten von Basidiomyceten-Hyphen im Normalzustand und nach Frosteinwirkung, Protoplasma 51: 523-538.

Kwiatkowska M., 1961, Elajoplasty goryczek cz. II. Obserwacje na materiale utrwalonym, Acta Soc. Bot. Pol. 30: 371-380.

Kwiatkowska M., Investigation on the elaioplast of Ornithogalum umbellatum L., Acta Soc. Bot. Pol. 30: 7-16.

Kwiatkowska M., 1970, Cold induced changes in the morphology of mitochondria in coleoptiles of corn of different frostresistance, Acta Soc. Bot. Pol.

Leninger A. L., 1964, The mitochondrion, Molecular basis of structure and function, New YorkAmsterdam.

Levitt J., Scatrh G., 1936, Frost-hardening studies with living cells, Canad. J. Res. C. 14, 267305.

Levitt J., 1956, The Hardiness of Plants, Academic Press Inc., New York.

Maszanckij V.F., Semichotova O.A., Buszujeva T., 1965, O svjazi morfołogiczjeskich i biochimiczjeskich priznakov povrjeżdjenija mitochondrij. Bot. Żurn. 50 (5): 639-646.

Mikulska E., 1957, Chloroplasty w liściach roślin zimozielonych, Acta Soc. Bot. Pol. 26 (3): 551 564.

Mikulska E., Żołnierowicz H., Wałek-Czernecka A., 1969, Ultrastruktura warstwy wyściełającej i periplazmodium w pylnikach Larix decidua Mill., Acta Soc. Bot. Pol. 38 (2): 290-301.

Moroz P., 1966, Luminjescjentno-mikroskopiczeskije nabludjenija procjessa zamjerzanija i ottaivanija żivotnych kletok, Biul. eksperim. bioł. i mjed. 62. (12): 109-111.

Morton W. M., 1969, Effect of freezing and hardening on the sulfhydryl groups of protein fraction. from cabbage leaves, Plant. Physiol. 44 (2): 168-172.

Olszewska M. J., Rodkiewicz B., 1963, Wpływ obniżonej temperatury na włączanie adeniny ${ }^{14} \mathrm{C}$, fenyloalaniny ${ }^{14} \mathrm{C}$ i tymidyny $3 \mathrm{H}$ do komórek merystemu korzeniowego Vicia faba, Acta Soc. Bot. Pol. 32: 409-426.

Pease D. C., 1967, The preservation of tissue fine structure during rapid freezing, J. Ultrastruct. Res. 21 (1-2): 98-124.

Rottenburg W., 1968, Die Standardisierung von Frostresistezuntersuchungen, angewandt an Aussenepidermiszellen von Allium cepa L., Protoplasma 65 (1-2): 37-48.

Sakai A., 1955, The seasonal changes of the hardiness and the physiological state of the cortical parenchyma cells of mulberry tree, Low Temp. Sci. Ser. B. 13: 33-41.

Siminovitch D., Rheaume B., Sachar R., 1967, Seasonal increase in protoplasm and metabolic capacity in tree cells during adaptation to freezing, Molec. Mech. Temperat. Adaptat. Washington. D. C., 1967, 3-4 (za ref. Ż.).

Thimann K. V., Kaufmann u. D., 1958, Cytoplasmic streaming in the cambium of white pine, Physiology of Forest Trees, Ed. by K. V. Thimann, The Ronald Press Co., N. Y. 
Tkaczuk V. A., 1967, Submikroskopiczjeskoje strojenije chłoropłastov zimnich i lestnich lis’tjew zimujuszczjego gorocha, Izd. A. N. Mołd. ZSRR, Sjer. bioł. i chim. 1966/1967, 7: 65-66. Tumanov I. I., 1951, Osnovnyje dostiżenija sovjetskoj nauki v izuczjenij morozostojkosti rastjenij, Timirjazjevskije cztjenija, T. 11, Izd. AN SSSR.

Tumanov I. I., 1960, Sovrjemjennoje sostojanije i oczjerjednyje zadaczi fiziołogii zimostojkosti rastjenij, Fiziołogija ustojczivosti rastjenij, Moskva, izd. Nauka.

Tumanov I. I., Trunova T. I., 1963, Pjervaja faza zakalivanija k morozu ozimych rastjenij v tjemnotje na rastvorach sacharov, Fizjołogija rastjenij 10 (2): 176-188.

Ullrich H., Heber U., 1957, Über die Schutzwirkung der Zucker bei der Frostreistenz von Vinterweizen, Planta 48 (6): $724-728$.

Ullrich H., Heber U., 1958, Über das Denaturieren pflanzlicher Eiweib durch Ausfrieren und seine Verhinderung, Planta 51 (4): 399-413.

Wałek-Czernecka A., Kwiatkowska M., 1961, Elajoplasty ślazowatych, Acta. Soc. Bot. Pol. 30 (2): $345-365$.

Yoshida Schizuc, Akira Sakai, 1967, The frost-hardening process of wood plant. XII. Relation between frost resistance and various substances in stem of black locust trees, Low Temp. Sci. Ser. B, Biol. Sci. 25: 29-44.

\section{Cytologiczne zmiany w epidermie koleoptyli Agropyron glaucum zwiazane z procesem} adaptacji do niskich temperatur

\section{Streszczenie}

Badano epidermę koleoptyli siewek Aropyron glaucum L. wyhodowanych w ciemności przy t. $+25^{\circ} \mathrm{C}$ i poddanych dwufazowej adaptacji do zimna. Prowadzono przyżyciowe obserwacje w mikroskopie świetlnym i badania w mikroskopie elektronowym po utrwaleniu materiału w aldehydzie glutarowym z postfiksacją czterotlenkiem osmu.

Dla I fazy hartowania kiełków (t. $0^{\circ} \mathrm{C}$ przez ok. 7 dni) charakterystyczne jest: a) pojawianie się mitochondriów o kształcie długich pałeczek oraz stopniowe rozjaśnianie matrix mitochondriów; b) wydłużanie się plastydów i zanikanie w nich skrobi; c) rozjaśnienie cytoplazmy podstawowej bez zmiany konfiguracji retikulum endoplazmatycznego; d) zwiększanie liczby kul lipidowych w najbardziej szczytowych komórkach epidermy.

II faza $\left(-4^{\circ} \mathrm{C}\right.$ przez ok. 7 dni) charakteryzuje się: a) pęcznieniem mitochondriów i dalszym rozjaśnieniem ich matrix oraz redukcją kristae; b) pęcznieniem plastydów; c) rozpadem cystern retikulum na wakuole i pęcherzyki z redukcją liczby rybosomów do niego przylegających; d) skupianie się kul lipidowych w struktury przypominające elajoplasty.

Wygląd komórek I fazy hartowania pozwala sądzić, że mogą się w nich odbywać procesy syntezy. Cytoplazma i mitochondria w okresie II fazy mają cechy charakterystyczne dla tkanek nieaktywnych lub degenerujących.

Kierownictwu Instytutu Cytologii i Genetyki SOAN ZSRR w Nowosybirsku składam serdeczne podziękowanie za umożliwienie wykonania eksperymentów i zdjęć w mikroskopie elektronowym.

Katedra Anatomii $i$ Cytologii Roślin

Uniwersytetu Eódzkiego 